\title{
Taching Critical Thinking In Reading By Using Three Stay One Stray
}

\author{
Muhammad Muhlisin, Fathurrahman Imran \\ Email: muhlisinzeko@gmail.com
}

\begin{abstract}
This research was aimed to find out The Effect of Three Stay One Stray towards Students' Critical Thinking in Reading at MTs NW Darusollihin Kalijaga. The subject of this study was 51 students at second grade of MTs NW Darusollihin Kalijaga. The gorup divided to two classes; they were experiment and control class. 26 students in experimental class and 25 students in control class. In which experiment class consists of 12 males and 14 females and in control class consists of 10 males and 15 females. The researcher gave the critical thinking in reading test by using Three Stray One Stray Strategy to find the students' critical thinking in reading. In analyzing the data the researcher used descriptive statistics and infrential statistics. Based on the data analysis was gotten that t-test was higher than t-table $(5.325>1.753)$ with signification level 5\%. Therefore alternative hypothesis accepted and null hypothesis rejected. Therefore, it concluded that there was significant effect of Three Stay One Stray towards Students' Critical Thinking in Reading at MTs NW Darusollihin Kalijaga. Keyword: Critical Thinking, Reading, Using Three Stay One Stray
\end{abstract}

\section{INTRODUCTION}

\section{Background of the study}

Reading is one of the basic language skills. It is one of the important elements in language skills. Through reading can bridge someone to know something new or important knowledge and reading activity is also a mean to connect the reader and the writer's idea. People can read anything that they like and it is one of joyful activity. In addition, people can read anywhere as long as they felt comfortable. However, reading is not the isolated process. Reading helps the students become better writers. Through reading, students have incidental contact with the rule of grammar. Students develop a sense for the structure of the language in grammar and increase their vocabulary, (Johnson, 2008:7).

Having ability to think critically is an important skill that should be possessed by all students. According to Richard and Linda (2006:14), critical thinking is the disciplined art of ensuring that the people use the best thinking they are capable of in any set of circumstance. The general goal of thinking is to figure out some situation, solve some problem, answer some question, or resolve some issues. We must all make sense of the world in which we live. How well or poorly we do this is crucial to our well-being.

In critical thinking itself, the students need to use several elements of critical thinking, they are purpose (goal, objectives), question, (issue, problem), information (data, facts, observations, experiences), interpretation and inference (conclusions, solutions), concept (theories, definitions, laws, principles, models), assumptions (presuppositions, axioms, taking for granted), implication and consequences, point of view (frames of reference, perspectives, orientation), (Paul \& Elder, 2006).

In reading activities, there is a critical thinking that also needs to be possessed by each student to think more critically in solving problems and understanding the reading material. Critical thinking in reading trains students to respond and identify points from the text. So, it can make students motivated to explain their arguments.

\section{Significance of Study}

Theoretically, the researcher of the study may give some information in learning English especially reading by using Three stay One Stray strategy. This research also informs the English teacher of the senior high school that there are many ways of teaching reading 
and the ways can be applied to the students well.

\section{Review Of Related Literature Reading}

According to Johnson (2008:4) reading is a constantly developing skill.Like any skill, we get better at reading by practicing. And conversely, if we do not practice, we will not get better and our skills may deteriorate. From age three to one hundred and three, reading practice is what helps us become better readers.

Linse (2005: 69) argued that reading is making sense of printed word. However, teaching reading comprehension is not an easy job for the teacher. The teachers need to improve their teaching method or strategy in order to help the students to get the point in reading text. In order to know the meaning of printed word in reading, the readers need to read comprehensively.

\section{Definition of Critical Thinking}

According to Paul \& Elder (2006:13) critical thinking is the art of thinking about thinking while thinking in order to make thinking better. It involves three interwoven phases: it analyzes thinking, evaluates thinking and improves thinking. Critical thinking is the process of analyzing and assessing thinking with a view to improving it. Critical thinking presupposes knowledge of the most basic intellectual standards for thinking (universal intellectual standards). The key to the creative side of critical thinking (the actual improving of thoughts) is in restructuring thinking as a result of analyzing and effectively assessing it.

Richard Paul \& Linda Elder also state that critical thinking is that mode of thinking about any subjects, content, or problem in which the thinker improves the quality of his or her thinking by skillfully analyzing, assessing and reconstructing it. Critical thinking is selfdirected, self-discipline, self-monitored, and self-corrective thinking. (2006:19)

\section{Definition of Three Stay One Stray}

Three Stay one Stray offers a low-threat forum where students can exchange ideas and build social skills such as asking probing questions. It also offers students the opportunity to learn by teaching. Placing the report-out responsibility on the students reinforces the valuable conception that knowledge resides within the learning community, not just with the "authority-figure" instructor (Millis, 2011).

\section{The Step of Using Three Stay One Stray}

Firstly, Students get worksheet and discuss it together in their own group.after that, in a given time, teacher asks one student from every group goes to the other group to see or take the information (the student who goes is determined by the teacher). And the, three other students stay in group to give the result of their discussion to quest.

The student who stray gets back to his/her own group and tell the member what information she/he has gotten.Every group checks the finding and rehashes their group result.During teaching and learning process, teacher's and students' activities would be observed. The researcher will use observation sheets and field notes in noting all things happened while doing the research. In this reflection phase, the researcher specified and analyzing what she has done in teaching activity in the classroom.

\section{RESEARCH METHOD}

\section{Research Design}

This research was designed to find out the effect of Three Stay One Stray towards students' critical thinking in reading at MTs NW DarusollihinKalijaga. The method that was used by the researcher in this study was quasiexperimental with the Non-equivalent Control Group Design.

\section{Population Study}

Population of this research was all students of second grade students at MTs NW DarusollihinKalijaga. However, the sample of this research was the second grade students of MTs NW DarusollihinKalijaga.

Technique of Data Collection

There were two steps of technique of data collection procedure such as 
1. Pre-test, the researcher used pre-test at the first meeting, because the researcher wanted to know the students basic skills of critical thinking in reading.

2. Post-test, the post-test after carrying a treatment for students to find out the effect of Three Stay One Stray towards students' critical thinking in reading.

\section{Data Analysis Procedure}

The researcher analyzed the numerical data, first the researcher tried to get the average of students' critical thinking in reading score within one step. It used to know how good students' ability to think critically in reading skill.Those analysis used descriptive analysis and inferential statistic.

\section{RESEARCH FINDING AND DISCUSSION}

Afterr doing computation and analysis of the data,where in the pre-test of experimental class, the students mean score was 41.3846 where there were 5 students passing the Criteria for Minimum Achievement and the percentage was $19 \%$ and in the post-test of experimental class, the students mean score was 59.0769, there were 21 students passing Criteria for Minimum Achievement and the percentage was $80.7 \%$. Meanwhile, in the pre-test of control class, the students mean score was 32.6400 where there were 3 students passing the Criteria for Minimum Achievement and the percentage was $11.5 \%$. Meanwhile, in the post-test of control class, the students mean score was 52.9600, there were 12 students passing Criteria for Minimum Achievement and the percentage was $46 \%$.Based inferential analysis was gotten that was gotten that t-test was higher than $\mathrm{t}$ table $(5.325>1.753)$ with signification level $5 \%$. Therefore alternative hypothesis accepted and null hypothesis rejected. Therefore, it concluded that there was significant effect of Three Stay One Stray towards Students' Critical Thinking in Reading at MTs NW DarusollihinKalijaga.

\section{Conclusion}

Finally after Analyze the data, the researcher found that students who were taught by using Three Stay One Stray got higher score than those students were not. From all of the discussion of this thesis, the researcher concludes that using Three Stay One Stray is one of the ways to improve students' critical thinking in reading, here the researcher conducted the research at MTs NW DarusollihinKalijaga.

\section{SUGGESTION}

Based on the conclusion above, the researcher offers some suggestions to be considered by English teacher, students and for the next researchers.

1. For English teacher. The first, teacher can make the students to be more active in the class by using an appropriate teaching strategy that is Three Stay One Stray strategy. The second, English teacher should apply Three Stay One Stray strategy in order to increase students' critical thinking in reading, because this strategy is able to motivate the students in learning English especially reading.

2. For the Students.The result of this study hopefully could create students' interesting in learning by using Three Stay One Stray strategy, so the process of teaching learning will be more fun.

3. For the Next Researcher. The researcher hopes that the result of this study is useful for the next researcher as reference for those who are interested in English and for who want to conduct further research about the use of Three Stay One Stray strategy, especially in another differentskill.

\section{BIBLIOGRAPHY}

A Committee of Specialists from Education Ministry. 2014-2015. Guided Reading Manual

Article of Muchsonah. 2015. Casting Critical Thinking in Critical Reading 
Instruction. University of Aberdeen, Scotland, United Kingdom

Johnson P. Andrew. 2008. Teaching Reading and Writing. United State of America: Published by Rowman \& Littlefield Education

Kagan Spencer. 2009. Kagan Cooperative Learning

Kothari C. R. 2004. Research Methodology.New Delhi: Published by New Age International (P)

L. Elizabeth Chesla. 2000. Learning Express, LLC. United State: Published by LearningExpress, LLC, New York.

Miller Steve. 1984. Experimental Design and Statistics. NW Putri NarmadaPaul Richard \& Elder Linda. 2006. Critical Thinking. United State of America: Published by Prentice Hall

Singh Kultar. 2007. Quantitative Social Research Method. New Delhi: Published by Sage Publications India Pvt Ltd

Sugiyono. 2007. StatistikUntukPenelitian. Bandung: Published by CV Alfabeta

Thesis of FitriaDewi. 2011. Three Stay One Stray Structure as a Method for Teaching Speaking at Senior High School. Semarang State University

Thesis of Rati Pertiwi. 2019. The Effectiveness of Building Team Communication Towards Students' Speaking Skill in Relation to Critical Thinking Skill at $M A$ 